\title{
ASSOCIATION AMONG SIZE OF THYMUS, ANTHROPOMETRIC DIMENSIONS AND NUMBER OF LYMPHOCYTES IN PERIPHERAL BLOOD IN NEWBORNS FROM SLOVAKIA
}

\author{
Ivan Vargaa ${ }^{\mathrm{a}, \mathrm{b}, \mathrm{c}}$, Frantisek Toth ${ }^{\mathrm{d}}$, Alexandra Uhrinova ${ }^{\mathrm{e}}$, Eva Nescakova ${ }^{\mathrm{f}}$, Stefan Polak $^{\mathrm{a}}$
}

a Department of Histology and Embryology, Faculty of Medicine, Comenius University in Bratislava, Sasinkova Street 4, 81108 Bratislava, Slovak Republic

${ }^{b}$ Department of Histology and Embryology, Faculty of Medical Specialty Studies, Slovak Medical University, Limbova Street 12, 83303 Bratislava, Slovak Republic

c Department of Laboratory Medicine, St. Elisabeth University of Health and Social Sciences, Palackeho Street 1, 81000 Bratislava, Slovak Republic

¿ Department of Gynaecology and Obstetrics, ForLife General Hospital, Medercska Street 39, 94501 Komarno, Slovak Republic

e Department of Radiology, ForLife General Hospital, Medercska Street 39, 94501 Komarno, Slovak Republic

${ }_{f}$ Department of Anthropology, Faculty of Natural Sciences, Comenius University in Bratislava, Mlynska dolina B1, 84215 Bratislava, Slovak Republic

e-mail: ivan.varga@fmed.uniba.sk

Received: January 1, 2009; Accepted: September 12, 2009

Key words: Thymus/Thymic index/Anthropometry/Number of lymphocytes/Newborns

Aims: Thymus is the central lymphatic organ in humans with important endocrine function that is involved in maturation of immunocompetent T-lymphocytes. In our study we investigated the relationship among thymus size and the anthropometric dimensions as well as between thymus size and the number of lymphocytes in peripheral blood in full-term newborns.

Methods: The examined group consisted of 212 full-term newborns from the region of Southern Slovakia. We examined birth weight, birth body length, head circumference and chest circumference. Thymus size was estimated by ultrasonography and it was expressed as Thymic Index. The number of lymphocytes in peripheral blood was determined from the number of total leukocytes and from the leukogram.

Results: We have found a statistically significant positive correlation among thymus size and the body dimensions of newborns. The highest correlation with thymus size was found for birth weight $(\mathrm{r}=0.409 ; \mathrm{P}<0.001)$ followed by birth body length $(r=0.368 ; P<0.001)$, head circumference $(r=0.365 ; P<0.001)$ and chest circumference $(r=0.340$; $\mathrm{P}<0.001$ ). We have proven also a statistically significant positive correlation between the number of lymphocytes in peripheral blood and thymus size $(\mathrm{r}=0.208 ; \mathrm{P}=0.039)$.

Conclusion: Our results confirmed the findings of other authors about a close relationship of Thymic Index and basic body parameters in newborns.

\section{INTRODUCTION}

The thymus is a central (primary) lymphoid organ with an important endocrine function. It is a crossroad between the immune and the neuroendocrine systems ${ }^{1}$. From phylogenetical point of view, thymus played a key role in the evolution of animals during development of adaptive immune system; therefore it is an important feature separating higher vertebrates from other animals ${ }^{2,3}$.

The thymus plays an important role in providing a suitable microenvironment for the proliferation, differentiation and selection of $\mathrm{T}$ lymphocytes that are responsible for cellular imunity ${ }^{3-7}$. The differentiation of $\mathrm{T}$ cells is a carefully orchestrated process. Mature and immunocompetent $\mathrm{T}$ cells leave the thymus through blood and lymphatic vessels and migrate to the peripheral lymphoid organs, mostly to spleen and lymph nodes ${ }^{8,9}$.
During human ontogenesis, the thymus passes through marked morphological changes, including a rapid prenatal growth and postnatal, age-related involution. The highest immunological activity of the thymus is in the age of $6^{\text {th }}$ months after birth, when the thymus contains the highest overall numbers of developing lymphocytes ${ }^{10}$. After the $1^{\text {st }}$ year of life, the thymus undergoes a progressive reduction in size. These age-related changes in thymic structure are called as physiological involution ${ }^{11-14}$. Even though, the remaining tissue is able to produce immunocompetent $\mathrm{T}$ lymphocytes till a late age. It is therefore probable, that the thymus as an organ with an immune and endocrine function is important throughout lifetime ${ }^{15}$.

Investigation of the relationship between thymus size in newborns and their anthropometric characteristics is gaining new significance in recent years. According to the hypothesis of Godfrey et al. ${ }^{16}$ malnutrition of new- 
Table 1. Basic characteristics of 212 full-term newborns.

\begin{tabular}{|l|c|c|}
\hline & Mean & Standard Deviation \\
\hline Gestation age (months) & 39.81 & 0.91 \\
\hline Birth weight $(\mathrm{g})$ & 3382.78 & 439.30 \\
\hline Birth lenght $(\mathrm{cm})$ & 49.82 & 2.07 \\
\hline Head circumference $(\mathrm{cm})$ & 34.42 & 1.19 \\
\hline Chest circumference $(\mathrm{cm})$ & 33.76 & 1.66 \\
\hline Thymic index & 9.08 & 2.46 \\
\hline Total number of leukocytes in peripheral blood & $12.68 \times 10^{6}$ & $4.93 \times 10^{6}$ \\
\hline Total number of lymphocytes in peripheral blood & $4.72 \times 10^{6}$ & $1.82 \times 10^{6}$ \\
\hline
\end{tabular}

Table 2. Statistical analysis of correlation between Thymic index and anthropometric dimensions and Thymic index and number of lymphocytes in peripheral blood.

\begin{tabular}{|l|c|c|}
\hline \multicolumn{1}{|c|}{$\mathrm{n}=212$} & Spearman's $\mathrm{r}$ & $\mathrm{P}$ - value \\
\hline Thymic index and birth weight & 0.409 & $<0.001$ * \\
\hline Thymic index and birth lenght & 0.368 & $<0.001^{*}$ \\
\hline Thymic index and head circumference & 0.365 & $<0.001$ * \\
\hline Thymic index and chest circumference & 0.340 & $<0.001$ * \\
\hline Thymic index and number of leukocytes in peripheral blood & 0.104 & $0.306 \mathrm{NS}$ \\
\hline Thymic index and number of lymphocytes in peripheral blood & 0.208 & $0.039 *$ \\
\hline
\end{tabular}

* statistically significant, NS - non significant

Table 3. Association between Thymic index and birth weight, and Thymic index and birth lenght, according several authors.

\begin{tabular}{|l|c|c|c|}
\hline \multicolumn{1}{|c|}{ Authors } & $\begin{array}{c}\text { Number of } \\
\text { patients }\end{array}$ & $\begin{array}{c}\text { Correlation coefficient be- } \\
\text { tween Thymic index } \\
\text { and birth weight }\end{array}$ & $\begin{array}{c}\text { Correlation coefficient be- } \\
\text { tween Thymic index } \\
\text { and birth lenght }\end{array}$ \\
\hline Iscan et al. $^{28}$ & 65 & $0.375(\mathrm{P}=0.002)$ & $0.74(\mathrm{P}<0.01)$ \\
\hline Aaby et al. $^{29}$ & 278 & $0.406(\mathrm{P}<0.001)$ & $0.223(\mathrm{P}=0.002)$ \\
\hline Jeppesen et al. $^{27}$ & 80 & $0.81(\mathrm{P}<0.01)$ & $0.74(\mathrm{P}<0.01)$ \\
\hline Our results & 212 & $0.409(\mathrm{P}<0.001)$ & $0.368(\mathrm{P}<0.001)$ \\
\hline
\end{tabular}

borns in the later phase of gestation causes disproportional body growth with concomitant defects in thymus development. The hypothesis suggests that newborns with large head circumference have a rapid intrauterine growth. This causes in later phases of gestation malnutrition and disproportional growth of body and extremities with respect to head. Affected individuals have also defects in the development and functions of thymus that cause elevated levels of IgE antibodies in blood serum. As a consequence organism is predisposed for the de- velopment of atopy. The hypothesis of Godfrey et al. ${ }^{16}$ about disproportional growth of the head with respect to the trunk and extremities has found many supporters as well as opponents. It represents a basis for several works referring to the relationship between the anthropometric indicators in newborns and the development of allergic diseases ${ }^{17-20}$. However, the results of Benn et al. ${ }^{21}$ indicating a positive correlation between head circumference and thymus size in newborns disagree with this hypothesis. Similarly a large study performed in northern Europe on 


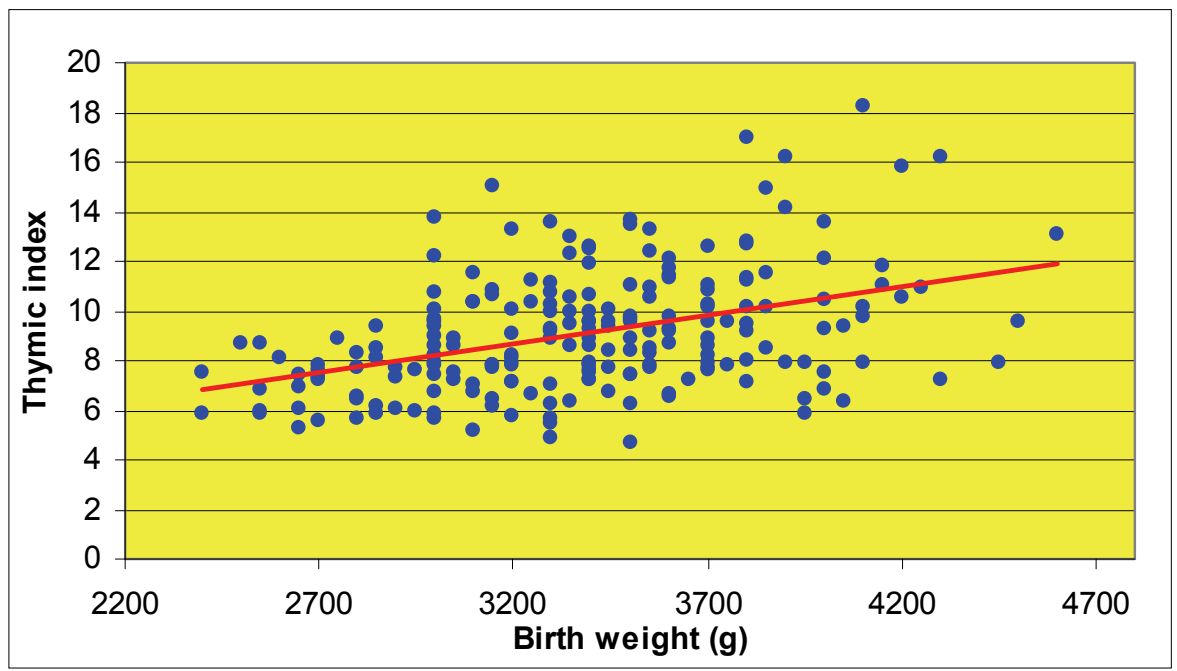

Fig. 1. Scatter plot of birth weight against value of Thymic index $(\mathrm{r}=0.409 ; \mathrm{P}<0.001)$.

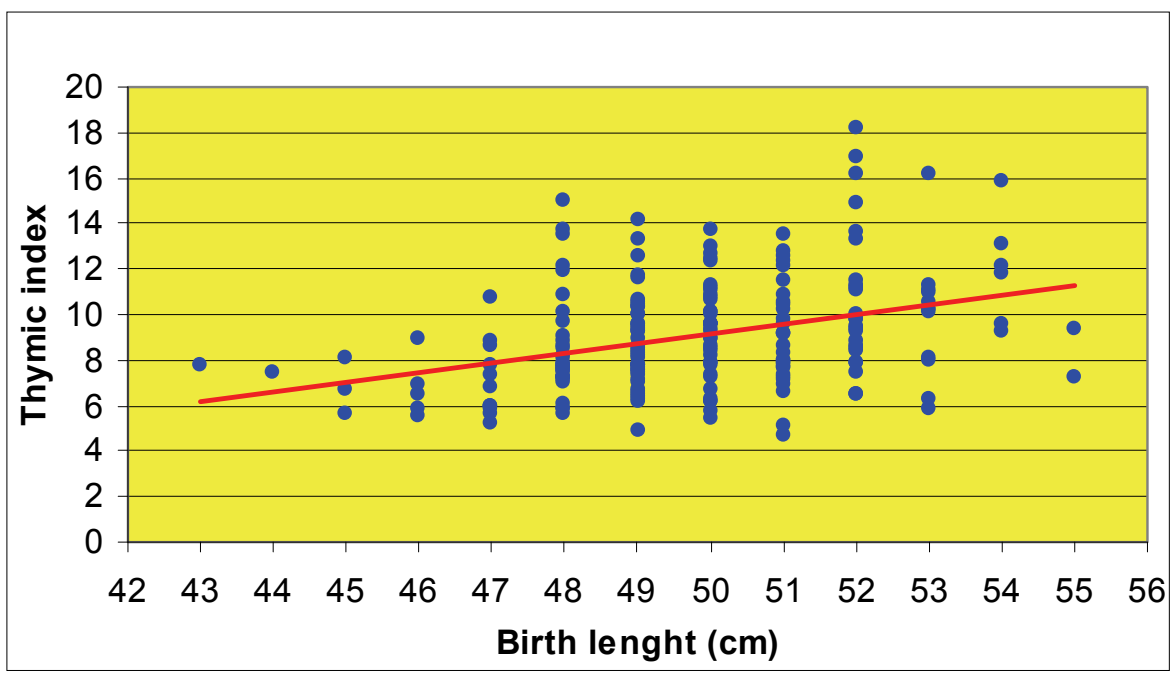

Fig. 2. Scatter plot of birth lenght against value of Thymic index $(\mathrm{r}=0.368 ; \mathrm{P}<0.001)$.

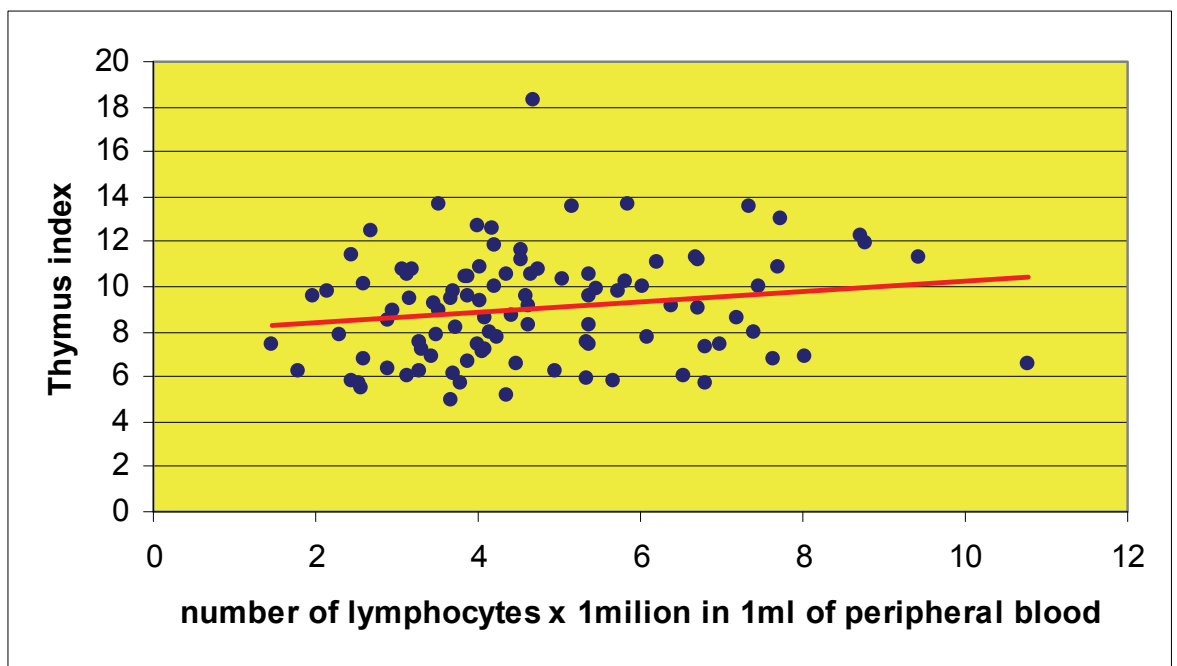

Fig. 3. Scatter plot of number of lymphocytes in peripheral blood against value of Thymic index $(r=0.208 ; \mathrm{P}<0.039)$. 
a group of 1683 adults born between 1947 and 1973 did not reveal any correlation between birth body weight, head circumference or level of IgE antibodies in the serum and the occurrence of allergic rhinitis or eczema ${ }^{22}$. Proponents of the Godfrey hypothesis are pointing to the fact that contradictory results can be caused by different sensibility of patients to aero-allergens that is dependent on geographical location and time (patients born several decades ago). Katz et al. ${ }^{23}$ examined the largest group so far consisting of 10809 adolescents. They also have found no correlation between the ratio of head circumference to birth weight and the incidence of allergic diseases.

\section{PATIENTS AND METHODS}

Examined group consisted of 212 newborns ( 122 boys and 90 girls) born in years 2005-2007 in General Hospital in Komarno, Slovak Republic. All newborns were delivered between the weeks 38 and 42 after gestation. Newborns with premature birth or newborns with symptoms of congenital infection, chromosomal aberration or malformation were not included in the examined group.

All newborns passed the anthropometric examination during the first five days after the delivery. Examined anthropometric parameters included birth weight, birth body length, head circumference and chest circumference.

The size of their thymus was estimated during the routine ultrasound examination of kidneys (in Slovakia is kidneys USG examination obligatory). At sonography the thymus appears as a well-delineated, echo-poor structure in the anterior mediastinum. Radiological studies of the thymus are really difficult to perform because the thymus is extremely variable in size, extension and shape. The thymus has lower echogenicity than the thyroid parenchyma. Methodology of the ultrasonography in newborns is described by Hasselbalch et al. ${ }^{24}$, Hasselbalch et al. ${ }^{25}$ and Tamasi et al. ${ }^{26}$. Ultrasound instrument HITACHI EUB-525 CFM was used for the measurement of thymus size. The linear $10 \mathrm{MHz}$ probe was applied during the examination suprasternally or subxiphoidally. Partially ossified sternum and intercostal spaces were also suitable for the ultrasound imaging. Thymus size was expressed according to the method of Hasselbalch et al. ${ }^{24}$ and Jeppesen et al. ${ }^{27}$ as the "Thymic Index". This index is calculated as the multiple of the largest transversal diameter (width) and the sagittal area of the largest thymus lobe in a longitudinal image.

Venous blood was sampled in 99 newborns. Total leukocyte count was determined by the instrument Automated Hematology Analyzer K-4500 (Toa Medical Electronics Co). Percentual share of individual white blood types (leukogram) was determined in blood smears stained by the standard Pappenheim method. These two values were used for the estimation of the number of lymphocytes in one milimeter of peripheral blood.

The value of correlation coefficient between the Thymic Index and anthropometric indicators as well as between the Thymic Index and the number of lym- phocytes was determined by Spearman's correlation. The closer is the Spearman's correlation coefficient (r) the value of 1 , the stronger is the correlation between two analyzed indicators. Levels of significance $\mathrm{P}<0.05$ were considered as statistically significant. All statistical calculations were performed by the software Statistical Package for the Social Sciences (SPSS) for Windows version 13.0.

\section{RESULTS}

Average values and standard deviations of the examined anthropometric indicators, of Thymic Index and lymphocyte number in peripheral blood are shown in Table 1 . We have found a statistically significant positive correlation between thymic size and examined anthropometric indicators. The highest correlation with thymus size was found for birth weight $(\mathrm{r}=0.409$; $\mathrm{P}<0.001)$, followed by birth body length $(\mathrm{r}=0.368$; $\mathrm{P}<0.001)$, head circumference $(r=0.365 ; \mathrm{P}<0.001)$ and chest circumference $(r=0.340 ; \mathrm{P}<0.001)$. Our results are summarized in Table 2.

Our results suggested that there is a statistically significant positive correlation between lymphocyte number in peripheral blood and thymus size $(\mathrm{r}=0.208$; $\mathrm{P}=0.039$; Fig. 3). We have found no correlation between the total number of leukocytes in peripheral blood and thymus size $(\mathrm{r}=0.104 ; \mathrm{P}=0.306)$.

\section{DISCUSSION}

Correlation between Thymic Index and birth weight or birth body length was described also by Iscan et al. ${ }^{28}$, Benn et al. ${ }^{21}$, Aaby et al. ${ }^{29}$, Jeppesen et al. ${ }^{27}$ and Park et al. ${ }^{30}$ (Table 3 ). On the contrary, Hasselbalch et al. ${ }^{31}$ found no correlation between thymus size and birth body length in the group of 149 full-term newborns. In accordance with Hasselbalch et al. ${ }^{25}$ and Jeppesen et al. ${ }^{27}$ we have estimated birth weight as the indicator showing the highest correlation with thymus size. In our group we have found a positive correlation also between thymus size and head circumference or chest circumference. Head circumference showed positive correlation with thymus size also in the study of Benn et al. ${ }^{21}$. This disproves the hypothesis of Godfrey et al. ${ }^{16}$ that newborns with large head circumference have smaller thymus and high predisposition to the postnatal development of allergy. According to Benn et al. ${ }^{21}$ there is also no relationship between smaller thymus size and development of allergic diseases during the first five years of life.

Investigations performed on patients living with HIV-1 infection show a positive correlation between thymus size and the number of CD4 ${ }^{+} \mathrm{T}-1 y m p h o c y t e s$ in peripheral blood. Premature involution of thymus entails also accelerated progression of HIV infection ${ }^{32}$. Enlargement of thymus in children infected by HIV virus is related to the regeneration of the number of $\mathrm{CD}^{+} \mathrm{T}$-lymphocytes in the blood during high-efficiency antiviral therapy ${ }^{33}$. Positive correlation exists also between the number of 
$\mathrm{CD}^{+} \mathrm{T}-1 \mathrm{ymphocytes}$ in peripheral blood and thymus size in healthy subjects ${ }^{34}$. Low number of lymphocytes in peripheral blood may indicate the involution of thymus in newborns with an acute disease ${ }^{35}$. However, Van Baarlen et al. ${ }^{36}$ have found neither a correlation between thymus size and the number of lymphocytes nor a correlation between thymus size and the size of other lymphatic organs in healthy children. Similarly Hasselbalch et al. ${ }^{31}$ did not find any correlation between thymus size and the percentile of $\mathrm{CD}^{+}$or $\mathrm{CD}^{+} \mathrm{T}$-lymphocytes in a group of 149 healthy children.

\section{CONCLUSION}

Basic methods in children health care include the examination of changes in the growth and development. Growth is one of the extraordinarily sensitive indicators of health status of an individual. Examination of body growth is therefore one of the mainstays of the preventive medicine. In addition to anthropometric parameters, thymus size can be another indicator of malnutrition, chronic disease or other negative factors. Our results confirmed the findings of other authors about close relationship between Thymic Index and basic body parameters in newborns.

\section{ACKNOWLEDGEMENTS}

This research was supported by the VEGA Grant from the Scientific Grant Agency of Ministry of Education of the Slovak Republic No. 1/3412/06 and Grant of Comenius University in Bratislava No. UK/451/2009.

\section{REFERENCES}

1. Geenen V, Brilot F. Role of the thymus in the development of tolerance and autoimmunity towards the neuroendocrine system. Ann N Y Acad Sci 2003; 992:186-95.

2. Bowden TJ, Cook P, Rombout JH. Development and function of the thymus in teleosts. Fish Shellfish Immunol 2005; 19(5):413-27.

3. Varga I, Pospíšilová V, Gmitterová K, Gálfiová P, Polák S, Galbavý Š. The phylogenesis and ontogenesis of the human pharyngeal region focused on the thymus, parathyroid, and thyroid glands. Neuroendcrinol Lett 2008; 29(6):837-45.

4. Anderson G, Jenkinson EJ. Lymphostromal interactions in thymic development and function. Nat Rev Immunol 2001; 1:31-40.

5. Staal FJT, Weerkamp F, Langerak AW, Hendriks RW, Clevers HC. Transcriptional control of T lymphocyte differentiation. Stem Cells 2001; 19:165-79.

6. Guyden JC, Pezzano M. Thymic nurse cells: a microenviroment for thymocyte development and selection. Int Rev Cytol 2003; 223:137.

7. Laurent J, Bosco N, Marche PN, Ceredig R. New insight into the proliferation and differentiation of early mouse thymocytes. Int Immunol 2004; 16(8):1069-80.

8. Kato S. Thymic microvascular system. Microsc Res Techn 1997; 38:287-99.

9. Dorko F, Kočišová M, Schmidtová K, Dorko E. Blood supply, lymphatic drainage, and the distribution of acetylcholinesterase (ACHE) - positive nerves in the rat thymus. Folia Veterinaria 1997; $41(3-4): 85-7$.
10. Weerkamp F, De Haas EFE, Naber BAE, Comans-Bitter WM, Bogers AJJC, Van Dongen JJM, Staal FJT. Age related changes in cellular composition of the thymus in children. J Allergy Clin Immunol 2005; 115(4):834-40.

11. Bodey B, Bodey BJr, Siegel S, Keiser HE. Involution of the mammalian thymus, one of the leading regulators of aging. In Vivo 1997; 11:421-440.

12. Dorko F, Kocisova M, Rybarova S, Dorko E. Acetylcholinesterasepositive innervation in the regenerated thymus in old rats after surgical and chemical castration. Bratisl Lek Listy 1998; 99(5):258-61.

13. Taub DD, Longo DL. Insights into thymic aging and regeneration. Immunol Rev 2005; 205:72-93.

14. Cavallotti C, D'Andrea V, Tonnarini G, Cavallotti C, Bruzzone P. Age-related changes in the human thymis studied with scanning electron microscopy. Microsc Res Techn 2008; 71:573-8.

15. Pospiśilová V, Varga I, Gálfiová P, Polák S̆. Morphological view on human thymus ontogenesis. Čes-slov Pediat 2008; 63(4):201-8.

16. Godfrey KM, Barker DJ, Osmond C. Disproportionate fetal growth and raised IgE concentration in adult life. Clin Exp Allergy 1994; 24(7):641-8.

17. Fergusson DM, Crane J, Beasley R, Horwood LJ. Perinatal factors and atopic disease in childhood. Clin Exp Allergy 1997; 27:1394401.

18. Oryszcyn MP, Annesi-Maesano I, Campagna D, Sahuquillo J, Huel G, Kauffmann F. Head circumference at birth and maternal factors related to cord blood total IgE. Clin Exp Allergy 1999; 29:334-41.

19. Bernsen RM, De Jongste JC, Koes BW, Aardoom HA, van der Wouden JC. Perinatal characteristics and obstetric complications as risk factors for asthma, allergy and eczema at the age of 6 years. Clin Exp Allergy 2005; 35:1135-40.

20. Carrington LJ, Langley-Evans SC. Wheezing and eczema in relation to infant anthropometry: evidence of developmental programming of disease in childhood. Matern Child Nutr 2006; 2:51-61.

21. Benn CS, Jeppesen DL, Hasselbalch H, Olesen AB, Nielsen J, Björkstén B et al. Thymus size and head circumference at birth and the development of allergic diseases. Clin Exp Allergy 2001; 31:1862-6.

22. Laerum BN, Svanes C, Wentzel-Larsen T, Gulsvik A, Iversen M, Gislason T. et al. The association between birth size and atopy in young North-European adults. Clin Exp Allergy 2005; 35:1022-7.

23. Katz KA, Pocock SJ, Strachan DP. Neonatal head circumference, neonatal weight, and risk of hayfever, asthma and eczema in a large cohort of adolescents from Sheffield, England. Clin Exp Allergy 2003; 33:737-45.

24. Hasselbalch H, Nielsen MB, Jeppesen D, Pedersen JF, Karkov J. Sonographic measurement of the thymus in infants. Eur Radiol 1996; 6 (5): 700-703.

25. Hasselbalch H, Jeppesen DL, Ersbøll AK, Nielsen MB. Thymus size in preterm infants evaluated by ultrasound. Acta Radiol 1999; 40:37-40.

26. Tamasi S, Rossi E, Carbone M, Amodio F, Mattace Raso M, Brunese L, Ciccarelli R, Vallone G. Echographic evaluation of the thymus gland in childhood. Radiol Med (Torino) 2000; 99(5):3524.

27. Jeppesen DL, Hasselbalch H, Nielsen SD, Sørensen TU, Ersbøll AK, Valerius NH, Heilmann C. Thymic size in preterm neonates: a sonographic study. Acta Pædiatr 2003; 92:817-22.

28. Iscan A, Tarhan S, Güven H, Bilgi Y, Yüncü M. Sonographic measurement of the thymus in newborns: close association between thymus size and birth weight. Eur J Pediatr 2000; 159:223-6.

29. Aaby P, Marx C, Traunner S, Rudaa D, Hasselbalch H, Jensen $\mathrm{H}$, Lisse I. Thymus size at birth is associated with infant mortality: a community study from Guinea-Bissau. Acta Pædiatr 2002; 91:698-703.

30. Park HY, Hertz-Picciotto I, Petrik J, Palkovicova L, Kocan A, Trnovec T. Prenatal PCB exposure and thymus size at birth in neonates in Eastern Slovakia. Environ Health Perspect 2008; 116:104-9.

31. Hasselbalch H, Jeppesen DL, Ersbøll, AK, Lisse IM, Nielsen MB. Sonographic measurement of thymic size in healthy neonates. Relation to clinical variables. Acta Radiol 1997; 38(1):95-8. 
32. Jeppesen DL. The size of the thymus: an important immunological diagnostic tool? Acta Pædiatr 2003; 92:994-6.

33. Cohen-Stuart JW, Slieker WA, Rijkers GT, Moest A, Boucher CA, Suur MH et al. Early recovery of CD4+ T lymphocytes in children on highly active antiretroviral therapy. Dutch study group for children with HIV infection. AIDS 1998; 7:1601-5.

34. Jeppesen DL, Hasselbalch H, Lisse IM, Ersbøll AK, Engelmann MDM. T-lymphocyte subsets, thymic size and breastfeeding in infancy. Pediatr Allergy Immunol 2004; 15:127-32.
35. Glavina-Durdov M, Springer O, Ćapkun V. Saratlija-Novaković Ž, Rozić D, Barle M. The grade of acute thymus involution in neonates correlates with the duration of acute illness and with the percentage of lymphocytes in peripheral blood smear. Biol Neonate 2003; 83:229-34.

36. Van Baarlen J, Schuurman HJ, Reitsma R, Huber J. Acute thymus involution during infancy and childhood: immunohistology of the thymus and peripheral lymphoid tissue after acute illness. Pediatr Pathol 1989; 9:261-75. 